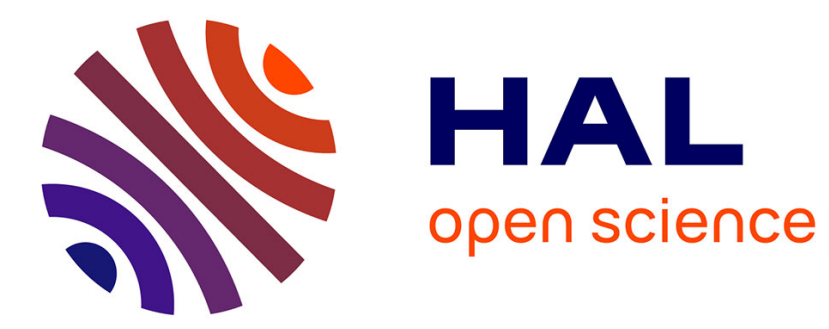

\title{
Study of the total lightning activity in a hailstorm
} Joan Montanyà, Serge Soula, Nicolau Pineda, Oscar van Der Velde, Pere Clapers, Glòria Solà, Joan Bech, David Romero

\section{To cite this version:}

Joan Montanyà, Serge Soula, Nicolau Pineda, Oscar van Der Velde, Pere Clapers, et al.. Study of the total lightning activity in a hailstorm. Atmospheric Research, 2009, 91 (2-4), pp.430-437. 10.1016/j.atmosres.2008.06.008 . hal-00441287

\section{HAL Id: hal-00441287 \\ https://hal.science/hal-00441287}

Submitted on 19 Feb 2022

HAL is a multi-disciplinary open access archive for the deposit and dissemination of scientific research documents, whether they are published or not. The documents may come from teaching and research institutions in France or abroad, or from public or private research centers.
L'archive ouverte pluridisciplinaire HAL, est destinée au dépôt et à la diffusion de documents scientifiques de niveau recherche, publiés ou non, émanant des établissements d'enseignement et de recherche français ou étrangers, des laboratoires publics ou privés.

\section{다)(1) $(5$}

Distributed under a Creative Commons Attribution - NonCommercial| 4.0 International 


\title{
Study of the total lightning activity in a hailstorm
}

\author{
Joan Montanyà a,*, Serge Soula ${ }^{\mathrm{b}}$, Nicolau Pineda ${ }^{\mathrm{c}}$, Oscar van der Velde $^{\mathrm{b}}$, Pere Clapers ${ }^{\mathrm{a}}$, \\ Glòria Solà ${ }^{\mathrm{a}}$, Joan Bech $^{\mathrm{c}}$, D. Romero ${ }^{\mathrm{a}}$ \\ a Electrical Engineering Department, Technological University of Catalonia (UPC), Colon, 1, Terrassa (Barcelona) 08222, Spain \\ b Laboratoire d'Aérologie, UMR 5560 CNRS/UPS, OMP, Université de Toulouse, Toulouse, France \\ c Meteorological Service of Catalonia, Barcelona, Spain
}

\begin{abstract}
A thunderstorm that developed over northeastern Spain on 16 June 2006 is analyzed. This severe thunderstorm produced hailstones as large as $40 \mathrm{~mm}$ and had a lifetime of $3 \mathrm{~h}$ and $30 \mathrm{~min}$. Radar cross-sections show strong vertical development with cloud echo tops reaching an altitude of $13 \mathrm{~km}$. The specific characteristics of the lightning activity of this storm were: (i) a large amount (81\%) of negative cloud-to-ground (-CG) flashes with very low peak currents ( $<10 \mathrm{kA}$ in absolute value), (ii) a very large proportion of intra-cloud (IC) flashes with an IC/CG ratio reaching about 400, (iii) a large number of "short" IC flashes (with only 1-VHF source according to SAFIR detection), (iv) a large increase of the -CG flash rate and of the CG proportion near the end of the storm. The rate of -CG flashes with a low peak current were observed to evolve similarly to the rates of IC flashes. Most of them have been assumed to be IC flashes misclassified by the Spanish Lightning Detection Network (SLDN). They have been filtered as it is usually done for misclassified +CG flashes. After this filtering, CG flash rates remained very low $\left(<1\right.$ min ${ }^{-}$ $\left.{ }^{1}\right)$ with +CG flashes sometimes dominant. All the particular lightning activity characteristics similar to those observed in the Severe Thunderstorm Electrification and Precipitation Study (STEPS) campaigns support the hypothesis that this thunderstorm could have had an inverted-polarity or complex charge structure. The maximum IC flash rate $\left(67 \mathrm{~min}^{-1}\right)$ peaked 24 min before the presence of reflectivity higher than $60 \mathrm{dBZ}$. The IC activity abruptly decreased during the period when reflectivity was dramatically increasing. The time of maximum reflectivity observed by radar was consistent with the times of reported hail at the ground.
\end{abstract}

\section{Introduction}

Severe thunderstorms frequently present dominant positive cloud-to-ground (CG) flashes for several tens of minutes during their mature phase (Carey and Rutledge, 1998; Lang et al., 2004; Soula et al., 2004; Wiens et al., 2005). Recently, Feng et al. (2007) showed that the percentage of +CG lightning in 10 severe hailstorms in Henan Province (China) was high with an average value of $45.5 \%$ while it was $8.15 \%$ on

\footnotetext{
* Corresponding author. Tel.: +34 66979 3316; fax: +34 937398236. E-mail address: montanya@ee.upc.edu (J. Montanyà).
}

average over a 3-year period for all storms occurring in the same area. However, severe weather often occurs without clustered or dominant +CG flash activity (Williams, 2001; Carey and Rutledge, 2003). From recent observations, Rust et al. (2005) and Wiens et al. (2005) explained the production of dominant $+\mathrm{CG}$ flashes by an inverted dipole charge structure. In the same way, they explained that a low CG rate could be due to the lack of a lower charge center (LCC) below the main charge at the middle level of the cloud. A recent study of thunderstorm modeling (Mansell et al., 2005) confirms the role of the LCC for the production of strong electric fields at an altitude which allows initiating CG flashes. Furthermore, the characteristics of the -CG flashes exhibit unusual values when the +CG are dominant, with lower peak 
currents and lower multiplicity values. For example, Soula et al. (2004) compared -CG flash characteristics in several cases of thunderstorms, mixing severe and non-severe storms or storms with severe and non-severe periods during their lifetime. The average values of the multiplicity and of the peak current for -CG flashes could be really low, close to 1.15 and $-12.5 \mathrm{kA}$, respectively, when +CG flashes were dominant.

Analysis of the total lightning activity (CG and intra-cloud (IC)) have been recently performed in several severe thunderstorms (Williams et al., 1999; Carey and Rutledge, 1998; Lang et al., 2000; Williams, 2001; Lang et al., 2004; Rust et al., 2005; Wiens et al., 2005). These studies generally report that IC flash rates increase substantially before the severe weather is observed at the ground. Inverted-dipole storms produce a lot of inverted-polarity IC discharges between the mid-level positive and upper negative charges instead of normal IC lightning flashes, which is indicated by the Lightning Mapping Array (LMA) observations (Wiens et al., 2005). In this process, the storms often develop a double inverted dipole structure $(+,-,+,-)$ in which inverted-polarity ICs occur independently in the upper and lower levels of the storm. Thus, these storms can be extremely active electrically, producing essentially continuous lightning in different parts of the storm (Krehbiel, 2007; Weiss et al., 2008).

An analysis of the total lightning flash rates of two thunderstorms that occurred over northeastern Spain was reported by Montanyà et al. (2007). In these cases, both thunderstorms presented a remarkable increase of IC activity before the severe weather at the ground. Both storms had low CG flash rates (lower than $2 \mathrm{~min}^{-1}$ ) and practically no CG activity during the presence of hail was suspected from high radar reflectivity values. The maximum IC flash rate was $92 \mathrm{~min}^{-1}$ and the peak IC/ CG flash ratio reached 60 . The lightning characteristics exhibited low values in terms of peak currents and multiplicity for -CG flashes. The cell classified as severe due to in-situ observations of hailstones larger than $19 \mathrm{~mm}$, produced +CG for a period of $1 \mathrm{~h}$, during which the peak currents of -CG flashes were low and their multiplicity was strictly one.

The present paper describes a detailed study of a hailbearing thunderstorm that occurred on June 16th of 2006 over the same region as that studied by Montanyà et al. (2007). The main goal of this paper is to discuss the occurrence of a large amount of low peak current -CG flashes. On that day, very warm and humid air was present at low levels, a weakening upper-level trough and cooler mid-level air mass provided favorable conditions for widespread thunderstorms in this region. The radio sounding made from Barcelona (1200 UTC) confirmed the instability according to several parameters: a Lifted Index of $-6 \mathrm{~K}$ (high instability), a K-Index of $36 \mathrm{~K}$ (high probability of thunderstorms) and a CAPE of $1302 \mathrm{~J} \mathrm{~kg}^{-1}$. Moreover, enhanced deep-layer shear and storm-relative helicity of $125 \mathrm{~m}^{2} \mathrm{~s}^{-2}$ over $0-3 \mathrm{~km}$ could enhance the chances of storms producing large hail, as the one considered in this study (see, for example, Das, 1962; Cheng and Rogers, 1988; Groenemeijer and van Delden, 2007).

\section{Data}

The region of Spain where the cell developed is well covered by several lightning detection networks and several meteorological radars. The Spanish Lightning Detection Net- work (SLDN) provided the CG lightning flash characteristics (time, location, polarity, multiplicity and peak current of the strokes) for this study. The SLDN consists of fifteen lowfrequency (LF) sensors distributed over the Iberian Peninsula with combined magnetic-direction-finding and time-of-arrival (MDF/TOA) techniques (Rivas Soriano et al., 2005). These sensors are of the same type as those of several networks, especially the National Lightning Detection Network (NLDN) in the US (Cummins et al., 1998, Orville, 2008) and the French network operated by Météorage. The SLDN has been evaluated several times and calibrated with the same procedures applied to the NLDN (Pérez Puebla, 2004, Murphy et al., 2002). The expected flash detection efficiency and the average location accuracy are $90 \%$ and $0.5 \mathrm{~km}$, respectively (Pérez Puebla, 2004; Rivas Soriano et al., 2005).

Additionally, Very High Frequency (VHF) sources associated with the total lightning activity were obtained from the Catalan Lightning Location Network (XDDE) operated by the Meteorological Service of Catalonia (SMC). The XDDE is composed of three VHF interferometers (Richard and Lojou, 1996) that cover the northeastern region of Spain where the hailstorm occurred. This network is limited to 100 detections per second providing 2D location of the VHF sources. The XDDE has been experimentally evaluated several times by means of electromagnetic field measurements and video recordings resulting in a flash detection efficiency of 93\% with an average VHF source-location accuracy of 0.5 km (Montanyà et al., 2006a). The XDDE source-grouping criteria are established so that two successive VHF sources are associated in the same flash if spatial and temporal intervals between them are lower than $7 \mathrm{~km}$ and $300 \mathrm{~ms}$, respectively.

Volumetric reflectivity values images were obtained from the three C-band radars operated by the SMC. These radars operate at long $(250 \mathrm{~km})$ and short $(130 \mathrm{~km})$ ranges performing every 6 min a series of 14 scans with elevation steps of $0.6^{\circ}$. In this work we use two kinds of display, vertical cross-sections of volumetric reflectivity and horizontal distributions of the maximum of the reflectivity in a given column (vertical projection). More details of the radar network are given by Bech et al. (2004).

\section{Analysis}

The 6-minute frequency of radar images allows a complete monitoring of the cell lifecycle. The evolution of the horizontal maximum reflectivity distribution and radar cross-sections are analyzed together with the total lightning activity. During the whole lifetime of the hailstorm, all of the +CG flashes presented a peak current greater than $10 \mathrm{kA}$, so no filtering of low peak current was applied (Cummins et al., 2006). On the other hand, $90 \%$ of the -CG flashes produced by the hailstorm showed peak current absolute values much lower than -10 kA and the median value of the peak currents for all -CG flashes was very low at about $-5 \mathrm{kA}$. Such an amount of -CG flashes with low peak currents is not consistent with the previous analysis of the SLDN (Rivas Soriano et al., 2005) and with the studies of severe storms in the same region (Montanyà et al., 2006b, 2007). In the description made by Cummins et al. (2006) it was found, in a specific region of US, that the majority of the low peak current $(<10 \mathrm{kA})$ negative discharges in the positive- 
dominant storms were detections of cloud discharges with a vertically oriented channel. Similar results were obtained by comparing the NLDN CG detections and the total lightning obtained by the Lightning Mapping Array (LMA) in a supercell in Oklahoma (Johnson and Mansell, 2006). In that study, Johnson and Mansell found several misclassifications of CG flashes that appeared to be due to either normal or inverted-polarity IC flashes. Finally, the authors concluded that a filtering cut-off of currents lower than $15 \mathrm{kA}$ (in absolute value) for both CG types would be suitable. For the present study, the occurrence of a large amount of small -CG discharges is discussed in Section 5.1. But in order to compute the rate of the $-\mathrm{CG}$ flashes, only those with peak currents greater than $10 \mathrm{kA}$ are considered.

Hail was confirmed by in-situ observations, with hailstones up to $40 \mathrm{~mm}$ in diameter. From the horizontal distribution of the maximum radar reflectivity, two cloud fractional areas, where the reflectivity exceeds thresholds of $55 \mathrm{dBZ}$ and $40 \mathrm{dBZ}$, respectively, are computed $(A(55)$ and $A(40)$, respectively). The thresholds $55 \mathrm{dBZ}$ and $40 \mathrm{dBZ}$ are assumed to be indicators of the presence of hail and of the convective region respectively (Montanyà et al., 2007). The hail proportion in the convective area of the cloud is estimated by calculating the ratio:

$A_{\mathrm{f}}(55)=\frac{A(55)}{A(40)}$

The time series of $A_{\mathrm{f}}(55)$ and of the different lightning flash rates corresponding to the whole cell is then analyzed.

\section{Overview}

The cell developed around 1136 UTC and moved northeastward until 1506 UTC. Fig. 1 displays the cell location at 1254 UTC in which white arrows indicate the locations of the start and end of the cell lifetime. During the $3 \mathrm{~h}$ and $30 \mathrm{~min}$ of the cell lifetime it covered a distance of $140 \mathrm{~km}$, resulting in an average velocity of $42 \mathrm{~km} \mathrm{~h}^{-1}$. The 15-dBZ reflectivity echoes reached an altitude of $13 \mathrm{~km}$ at 1224 UTC. Around 1300 UTC, hailstones with diameters up to $40 \mathrm{~mm}$ were reported at the ground. Table 1 summarizes different characteristics of the thunderstorm, related to its structure and to its lightning activity. The cell produced 58 -CG flashes (with currents $>10 \mathrm{kA}$ ), 39+CG flashes, 4560 IC

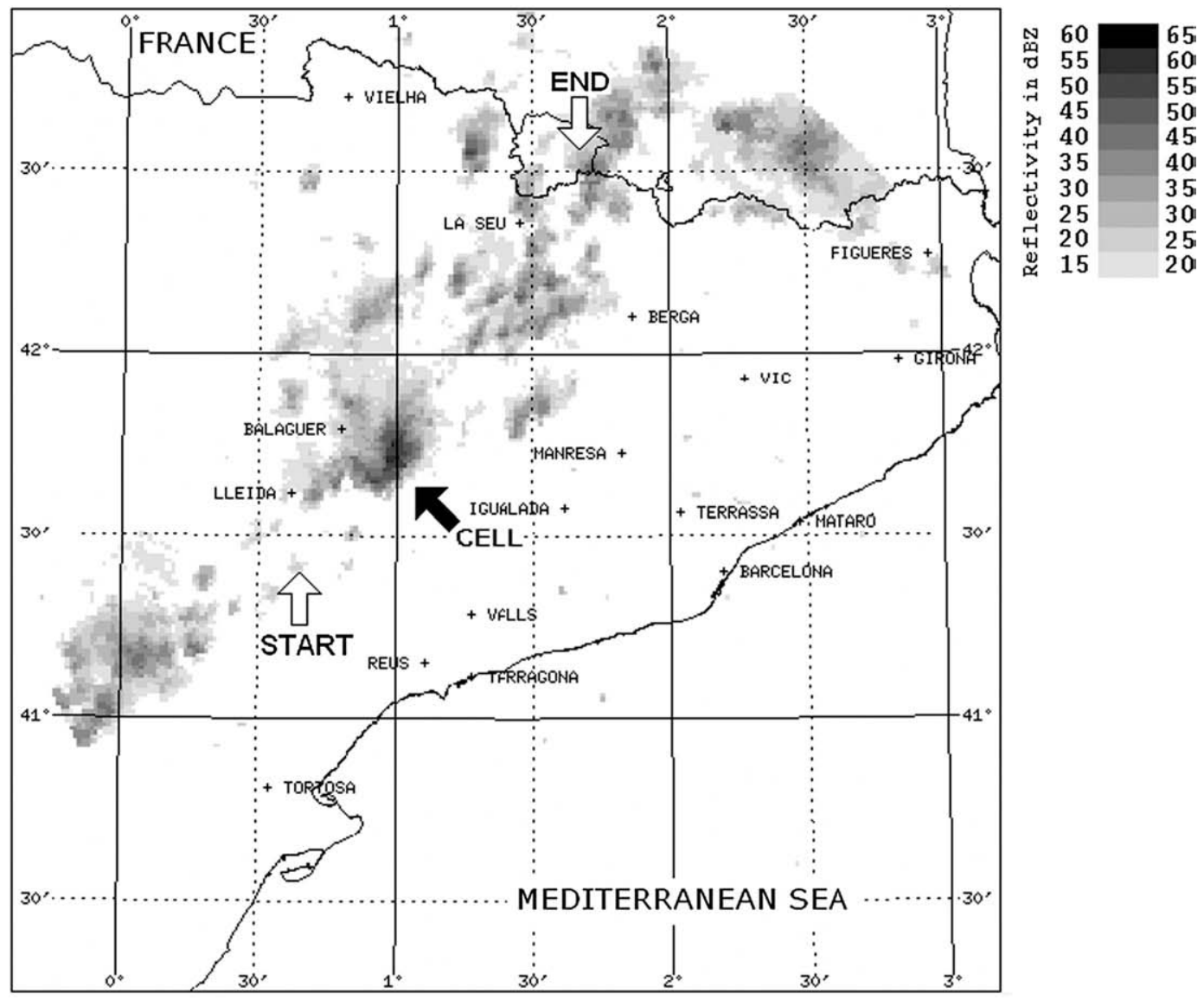

Fig. 1. Distribution of the maximum radar reflectivity at 1254 UTC in the region of north eastern Spain. The cell location is indicated with the black arrow. White arrows indicate the locations of the start (at 1136 UTC) and the end (at 1506 UTC) of the cell lifetime. Black circles correspond to the sites of the VHF sensors of the XDDE network. 
Table 1

Overall characteristics of the cell

\begin{tabular}{ll}
\hline Cell duration & $3 \mathrm{~h} 30 \mathrm{~min}$ \\
\hline -CG flashes & 312 \\
(-CG flashes with peak currents $>10 \mathrm{kA})$ & $(58)$ \\
+CG flashes & 39 \\
Average multiplicity (maximum) & $1.2(13)$ \\
IC flashes & 6585 \\
Average peak current for -CG $(\mathrm{kA})($ median) & $-6.8(5)$ \\
Average peak current for -CG $(>10 \mathrm{kA})(\mathrm{kA})$ & $-14.9(-13)$ \\
maximum -CG rate $\left(\mathrm{min}^{-1}\right)$ & 2.16 \\
Maximum +CG rate $\left(\mathrm{min}^{-1}\right)$ & 0.6 \\
Maximum IC rate $\left(\mathrm{min}^{-1}\right)$ & 67 \\
Maximum (\%) & $9 \%$ \\
Maximum cloud top $\left(\mathrm{km}^{-1}\right)$ & 13 \\
60-dBZ maximum altitude $(\mathrm{km})$ & 10 \\
(isotherm temperature at the corresponding altitude $\left.\left({ }^{\circ} \mathrm{C}\right)\right)$ & $(-47)$ \\
\hline
\end{tabular}

flashes with more than one VHF source and 20251-VHF source IC events. Fig. 2 displays the time series of the -CG and +CG flash rates, the IC flash rate, and the fractional area $A_{f}(55)$. During the first hour of the lifetime, the IC flash rate increased continuously, more and more abruptly to reach the maximum value of $67 \mathrm{~min}^{-1}$ at 1236 UTC while the -CG flash rate $\left(0 \mathrm{~min}^{-1}\right)$ and $+C G$ rate $\left(0.16 \mathrm{~min}^{-1}\right)$ remained very low. At that moment the ratio IC:CG reached very high values, around 400. After 1236 UTC, the IC rate decreased abruptly up to about $30 \mathrm{~min}^{-1}$ at 1254 UTC when the maximum reflectivity appeared. During this decrease, the +CG flashes were clearly dominant and $A_{\mathrm{f}}(55)$ reached its maximum value (9.1\%). After 1254 UTC the IC flash rate increased again and the CG flash rates remained low, during approximately $1 \mathrm{~h}$. The IC flash rate decreased progressively from 1348 UTC while the -CG flash rate exhibited a strong increase from 1424 UTC and largely dominated the +CG flash rate.

At 1200 UTC high values of the maximum reflectivity in the range of 55-60 dBZ occurred in the cloud. At surface level, such maximum values appeared from 1242 UTC to 1336 UTC (Fig. 2). In terms of vertical distribution, a core of these large reflectivity values was detected at an altitude of $10 \mathrm{~km}$ at 1242 UTC. This core rapidly descended to altitudes lower than $5 \mathrm{~km}$ at 1248 UTC. Then, at 1254 UTC, high reflectivity values up to $65 \mathrm{dBZ}$ appeared at altitudes lower than $3 \mathrm{~km}$ indicating the presence of hail close to the ground. Fig. 3 displays the horizontal distribution of the maximum of the radar reflectivity and two vertical cross-sections at 1236 UTC (a) and at 1254 UTC (b) i.e. at the time of the hail precipitation. For both instants, the location of the lightning activity occurring in $+/-3$ min after the radar scan is superimposed (the CG flashes with white marks and the IC flashes with ellipses). Only $1+C G$ flash occurred around 1236 UTC and 4 CG flashes (1 -CG and $3+C G$ ) occurred around 1254 UTC. The +CG flashes seem to be located closer to the high reflectivity regions. The IC flashes were predominantly located in a region extending from the high reflectivity core to a low reflectivity region. A large majority of the IC flashes were east-west-oriented, which seems to indicate a preferential direction of propagation for the IC lightning process.

\section{Discussion}

\subsection{Lightning flash characteristics}

From the total of the 312 flashes classified as -CG flashes by the SLDN, only 58 exhibited peak currents higher than $10 \mathrm{kA}$ in absolute value. With this amount of low peak current -CG flashes, the average peak current was $-6.8 \mathrm{kA}$ and the median was $-5 \mathrm{kA}$. Fig. 4 displays the evolution of the mean peak current for all -CG flashes detected by the SLDN. The average value remained low for a long period and increased abruptly at 1448 UTC. These very low values are much lower than the peak currents observed in the previous study of Montanyà et al. (2007) corresponding to the analysis of two hailstorms in the same region. It could suggest a possible SLDN misclassification for the low peak current -CG flashes. Unfortunately, the XDDE network is not able to determine the VHF sources altitude and to distinguish the leaders that lead to a ground stroke. Thus, we cannot check the possible misclassification of one system with the other.

Recent publications from STEPS presented an extensive number of studies of the total lightning activity of severe

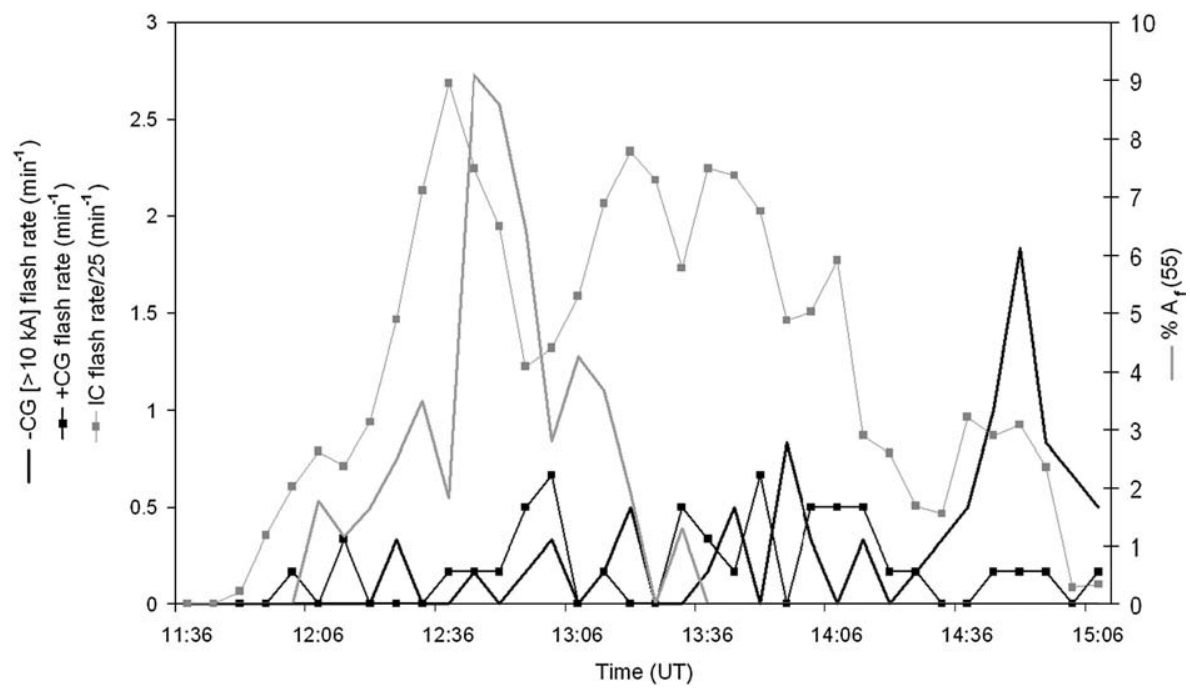

Fig. 2. Time series of different lightning flash rates and fractional area $A_{\mathrm{f}}(55)$. 
a)
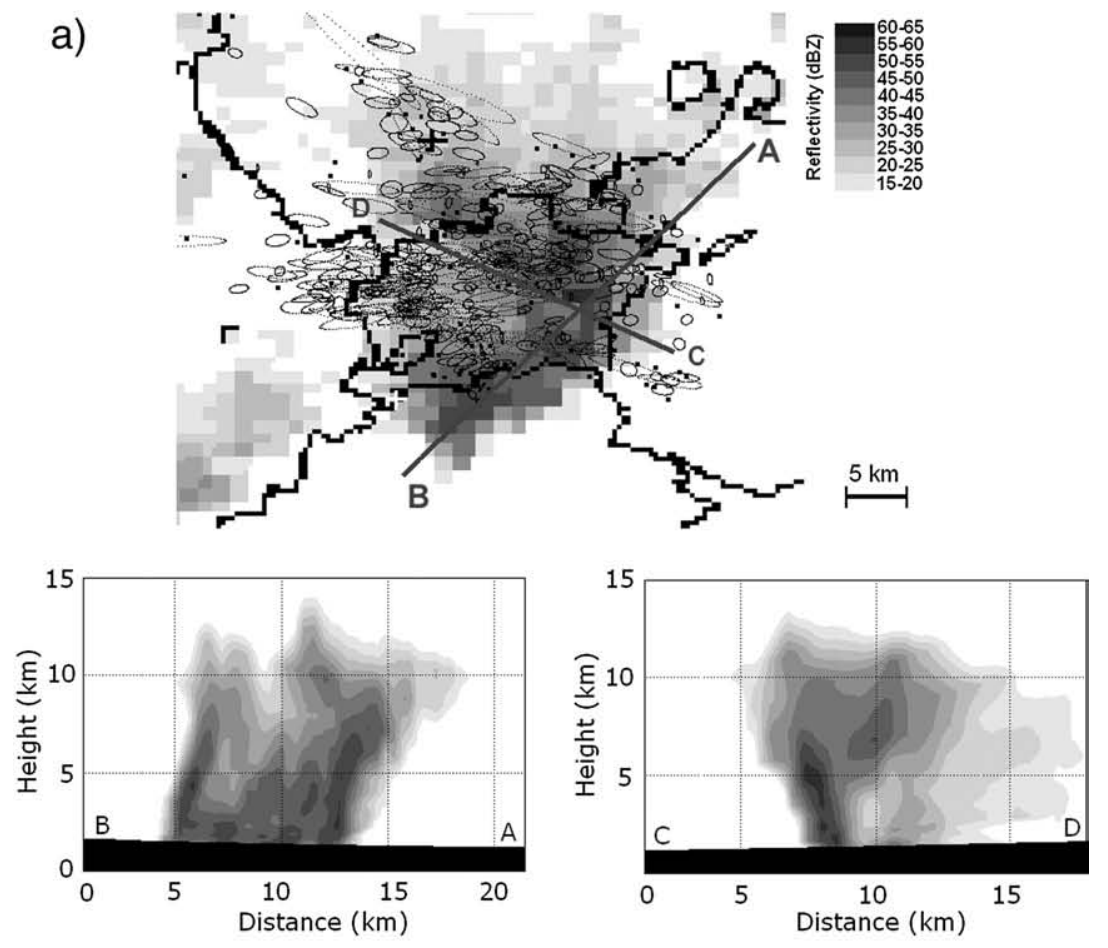

b)
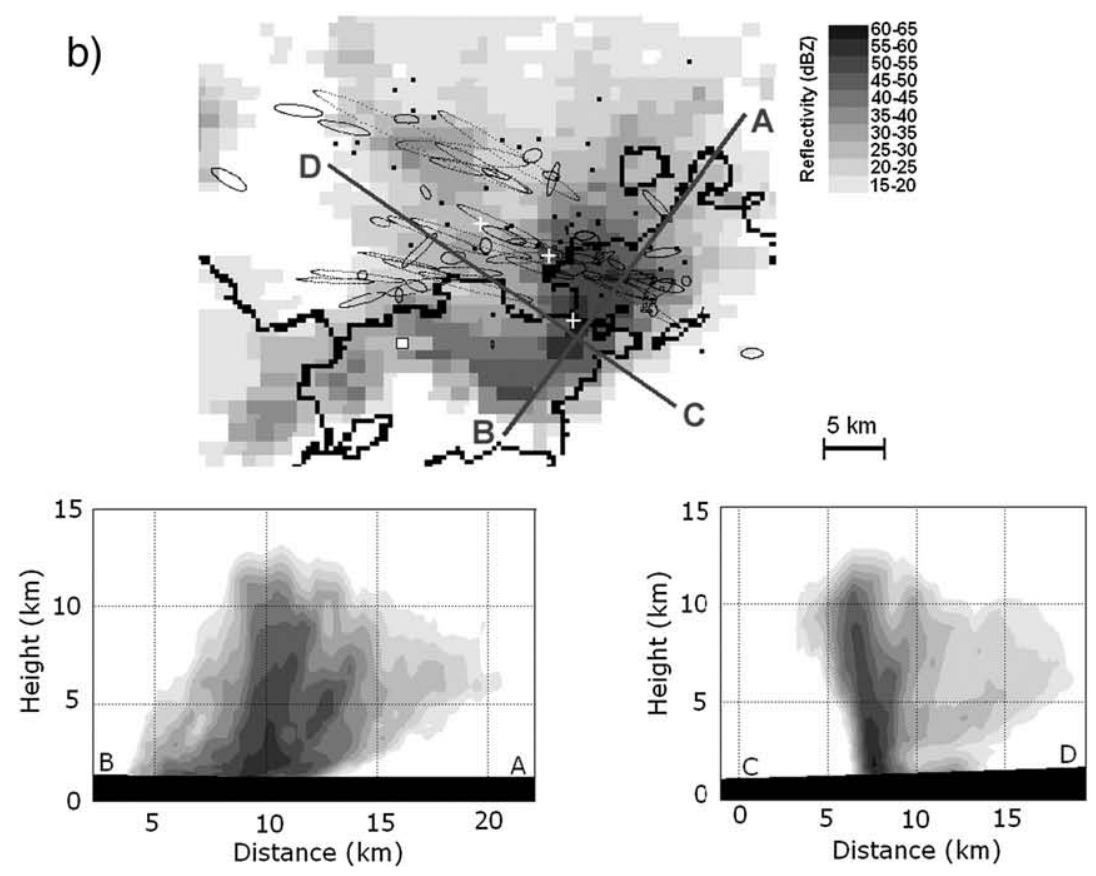

Fig. 3. Radar reflectivity and lightning activity around 1236 UTC (a) and around 1254 UTC (b). The IC groups of VHF sources are fitted into an ellipse, the isolated sources are indicated by small black squares, -CG and +CG flashes are plotted by white squares and white crosses, respectively.

storms by confirming several cases with inverted-polarity electrical structures or more complex structures (Rust and MacGorman, 2002; Rust et al., 2005; MacGorman et al., 2005; Wiens et al., 2005; Tessendorf et al., 2007; Weiss et al., 2008; Krehbiel, 2007). According to most of these papers, the inverted or complex charge structures could explain the low
CG flash rate from the absence of a low level charge centre (LPCC in the case of a normal dipole) and the predominant + CG in the CG lightning activity due to the mid-level positive charge. Additionally, inverted structures could favor the presence of IC flashes from the mid-level positive region to the upper negative region that would produce emissions 


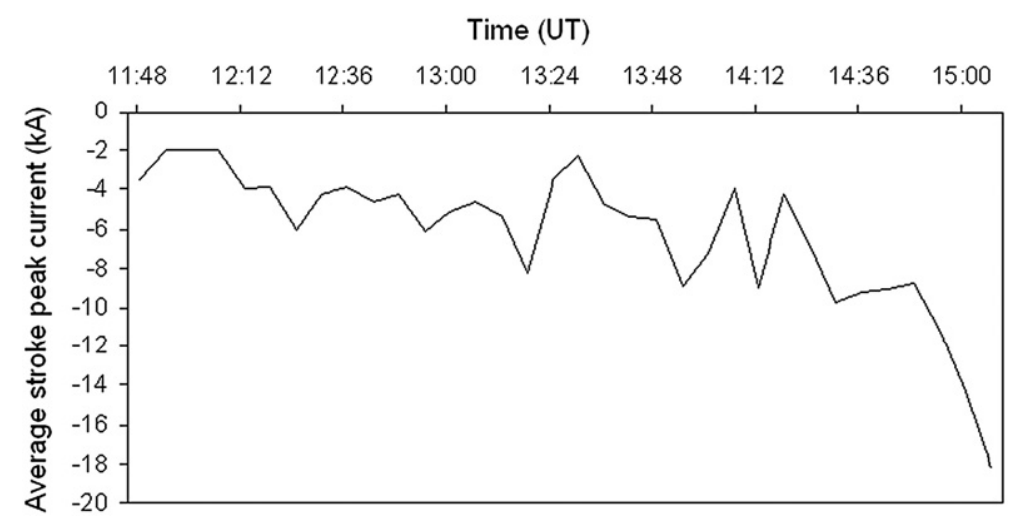

Fig. 4. Evolution of the mean peak current for the -CG flashes detected by the SLDN (before filtering).

similar to -CG flashes. In the present study, the singular behavior of the lightning activity leads the authors to assume the hypothesis that this storm may have been characterized by such an inverted or complex charge structure.

From this assumption, -CG flashes with peak currents lower than $10 \mathrm{kA}$ in absolute value were rejected. This threshold is consistent with that described by Cummins et al. (2006) and by Johnson and Mansell (2006), and discussed in Section 3. The increase of the -CG rate at 1448 UTC was simultaneous with an increase of the multiplicity which remained close to 1 for the -CG flashes with peak currents lower than $10 \mathrm{kA}$. After 1430 UTC, the number of strokes per -CG flash increased up to 13 (at 1448 UTC). Another analysis of the different kinds of lightning flash is made from the evolution of the cumulative numbers. Thus, Fig. 5 displays the cumulative flash number for several types of flash, IC, 1-VHF IC, +CG, -CG ( <-10 kA), and -CG $(>-10 \mathrm{kA})$ during the whole lifetime. The cumulative flash rates of -CG with peak currents of an absolute value lower than $10 \mathrm{kA}$ seemed to evolve similarly to that of IC flashes and differently from that of the other -CG flashes.

At 1418 UTC, the lightning activity corresponded to that of a typical thundercell with an increase of the CG flash proportion, usually with the +CG flash proportion increasing too, but in the present case with the -CG flash proportion increasing which can be due to the characteristic invertedpolarity electrical structure of the storm. Both -CG numbers seemed totally independent and the first one was in very good agreement with the IC flash number. This observation further suggests the need to filter the -CG flashes detected by the system to avoid IC flashes counted as -CG flashes.

After applying the current filtering, the average peak current was $-14.9 \mathrm{kA}$ (median -13 kA). For the +CG flashes the average peak current was $52 \mathrm{kA}$ (median $63.8 \mathrm{kA}$ ). By analyzing ten years of SLDN data, Rivas Soriano et al. (2005) found an average peak current of -27.5 kA (median -23.5 kA) for -CG flashes and $47.1 \mathrm{kA}$ (median $35.3 \mathrm{kA}$ ) for +CG flashes. Thus, the values calculated in this study for the negative flashes are much lower, while those obtained for the positive are really much higher. It could be more evidence of a complex or inverted charge structure.

The elevated proportion of IC discharges and the reduced CG activity could be also explained by means of the elevated charge hypothesis proposed by MacGorman et al. (1989). In comparison to the case analyzed by Montanyà et al. (2007) in the same region, the main difference is that in this case there is a significant proportion of +CG flashes supporting the hypothesis about the inverted charge structure.

\subsection{Lightning flash rates}

The thunderstorm considered in this study exhibited a singular behavior in comparison with typical storms in the region: a long lifetime (more than $3 \mathrm{~h}$ ), a CG flash rate remaining low $\left(<1 \mathrm{~min}^{-1}\right)$ during a long period, a +CG flash rate slightly higher during the same long period, and a very high IC flash rate (up to $67 \mathrm{~min}^{-1}$ ). In comparison, Pineda et al. (2007) analyzed the lightning activity produced by 9 convective episodes from this region and found for each episode much larger average CG flash proportion values (between $9 \%$ and 19\% over land) and much lower average +CG flash proportion values (lower than $10 \%)$. However, the features of the present thunderstorm correspond well with those of a thunderstorm analyzed by Montanyà et al. (2007). The chronology of the lightning activity, the time of the activity during the day, the size, the reflectivity values and their proportion in the cloud system exhibit similar trends in both cases. This analogy may indicate also that the features observed are characteristic of severe storms in the region. The observation of large hail at the ground allows characterizing the present storm as a severe storm and furthermore, the maximum radar echo tops reached $13 \mathrm{~km}$, which is comparable to the severe storm observed by Carey and Rutledge (1998). The radar images indicated the presence of hail at high altitude and then close to the ground. A few minutes before the occurrence of severe weather at the ground, the IC lightning activity abruptly increased without any marked increase of the CG flash rates. This observation agrees with some features of severe weather noted by Carey and Rutledge (1998), Williams et al. (1999), and Lang et al. (2000). Another particularity is the high proportion of 1-VHF source flashes when the IC flash activity was very strong, which could indicate frequent flash triggering but short propagations.

Other studies reported such short propagation and time flashes detected in electrically very active storms and with a dipolar structure anomalously charged (Dotzek et al., 2001, Hamlin, 2004; Krehbiel, 2007; Weiss et al., 2008). These storms produce continuous lightning in different parts of their structure and other processes than non-inductive ones could largely contribute to the electrification during these periods, like the ion deposition by the flashes themselves and 

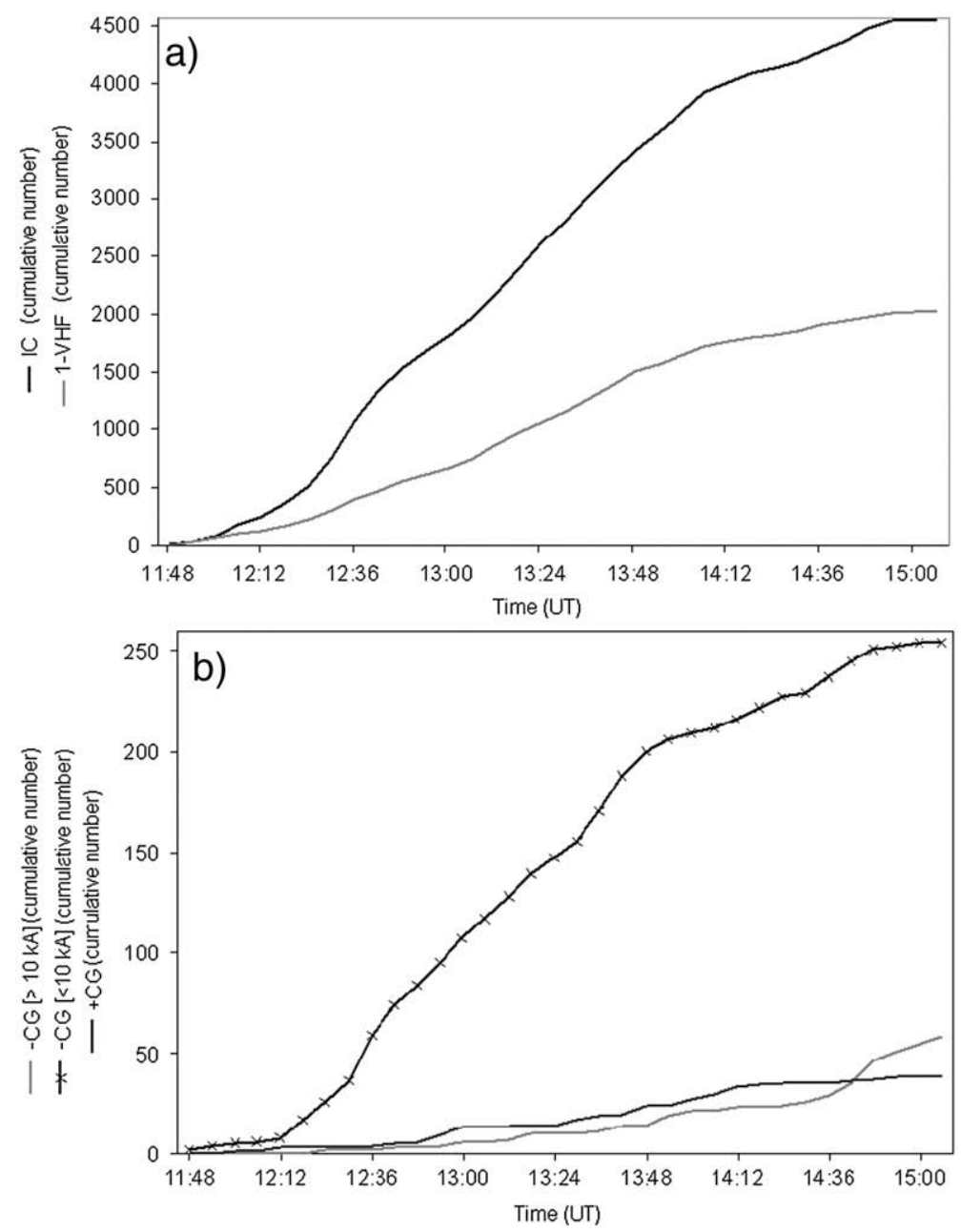

Fig. 5. Evolution of the cumulative flash numbers for a): the total IC activity, IC activity with 1-VHF sources, b): +CG, -CG with peak currents less than 10 kA and -CG with peak currents larger than $10 \mathrm{kA}$.

the inductive processes associated with the high electric fields produced by the charge depositions as selective ion capture by hydrometeors.

Most of the IC flashes with longer duration were oriented and located in a preferential direction in the convective system, respectively. The IC and -CG flashes tended to avoid the high reflectivity region and only a few +CG flashes were located near this region. It could indicate that these areas of high reflectivity did not contain large amounts of negative charge. After peaking, the IC flash rate abruptly decreased while the hail seemed to reach the surface. However the CG flash rate did not increase very much during the descent of the high reflectivity cores. The high IC flash rate previously observed was probably due to the combined presence of charge and better triggering conditions aloft. This aspect was discussed in Montanyà et al. (2007).

\section{Conclusion}

The total lightning activity and the reflectivity structure from C-band weather radars, related to a thunderstorm producing large hail, have been described. Both aspects and additional ground observations about hailstones with a diameter up to $40 \mathrm{~mm}$ allow us to classify the storm as severe with a lifetime of about $3 \mathrm{~h}$ and $30 \mathrm{~min}$. The radar images showed reflectivity values up to $65 \mathrm{dBZ}$ and a reflectivity core with values up to $60 \mathrm{dBZ}$ reached an altitude of $10 \mathrm{~km}$. During the mature phase of the storm, the cloud top reached $13 \mathrm{~km}$, the IC flash rate reached $67 \mathrm{~min}^{-1}$ and both -CG and +CG flash rates exhibited low values leading to a CG flash rate lower than $1 \mathrm{~min}^{-1}$. Thus, coinciding with the peak of IC activity, the IC/CG ratio reached a maximum value close to 400 . Among the IC flashes detected by the XDDE a large amount (about 31\%) were 1-VHF events which indicate short propagation lightning events. A large amount of the initial -CG flashes detected by the SLDN exhibited very low peak currents and low multiplicity values. Considering all -CG detections, the median value of the peak current was close to $-5 \mathrm{kA}$ and the average multiplicity was close to 1 .

The analysis of the evolution of different lightning flash categories shows the rate of the -CG flashes with a low peak current ( $<10 \mathrm{kA}$ in absolute value) evolved very similarly to that of the IC flashes and differently to that of the -CG flashes with a more typical peak current (>10 kA in absolute value). 
This could indicate a misclassification of IC flashes by the system of detection because vertically oriented IC flashes and -CG flashes produce LF radiation of similar polarity if occurring in an inverted charge structure. Other observations also lead to this assumption: the $+C G$ proportion was high $(>50 \%)$ during the mature phase, the rate and the multiplicity of the -CG flashes markedly increased at the end of the storm lifetime. By considering these observations the -CG flashes were filtered by using a criterion of minimum peak current fixed at $10 \mathrm{kA}$ in absolute value and thus, the -CG flash characteristics were closer to typical values for thunderstorms in the region. In conclusion, the features of this hailstorm correspond well to those revealed by several studies of severe storms cases from the STEPS experiment in the Great Plains area of the US.

\section{References}

Bech, J., Vilaclara, E., Pineda, N., Rigo, N.T., López, J., O’Hora, F., Lorente, J., Sempere, D., Fàbregas, F.X., 2004. The weather radar network of the Catalan Meteorological Service description and applications. European Conference on Radar in Meteorology and Hydrology (ERAD)-COST 717 Final Seminar, vol. 2, pp. 416-420.

Carey, L.D., Rutledge, S.A., 1998. Electrical and multiparameter radar observations of a severe hailstorm. J. Geophys. Res. 103 (D12), 13979-14000.

Carey, L.D., Rutledge, S.A., 2003. Characteristics of cloud-to-ground lightning in severe and non-severe storms over the central United States from 1989-98. J. Geophys. Res. 108 (D15), 4483. doi:10.1029/2002JD002951.

Cheng, L., Rogers, D.C., 1988. Hailfalls and hailstorm feeder clouds-an Alberta Case Study. J. Atmos. Sci. 45, 3533-3545.

Cummins, K.L., Murphy, M.J., Bardo, E.A., Hiscox, W.L., Pyle, R.B., 1998. A combined TOA/MDF technology upgrade of the U.S. National Lightning Detection Network. J. Geophys. Res. 103D, 9035-9044.

Cummins, K.L., Cramer, J.A., Biagi, C., Krider, E.P., Jerauld, J., Uman, M.A., Rakov, V.A., 2006. The U.S. National Lightning Detection Network: post-upgrade status. 2nd Conf. on Meteorological Applications of Lightning Data. Amer. Meteorol. Soc. . Atlanta, paper 6.1.

Das, P., 1962. Influence of wind shear on the growth of hail. J. Atmos. Sci. 19, 407-414.

Dotzek, N., Höller, H., Théry, C., Fehr, T., 2001. Lightning evolution related to radar-derived microphysics in the 21 July 1998 EULINOX supercell storm. Atmos. Res. 56, 335-354.

Feng, G., Qie, X., Yuan, T., Niu, S., 2007. Lightning activity and precipitation structure of hailstorms. 13th International Conference on Atmospheric Electricity, vol. 2. Beijing, China, pp. 541-544.

Groenemeijer, P.H., van Delden, A., 2007. Sounding-derived parameters associated with large hail and tornadoes in the Netherlands. Atmos. Res. $83,473-487$.

Hamlin, T. 2004. The New Mexico Tech Lightning Mapping Array. PhD. dissertation, New Mexico Institute of Mining and Technology, 164 pp.

Johnson, E.V., Mansell, E.R., 2006. Three dimensional lightning mapping of the central Oklahoma supercell on 26 May 2004. Second Conference on Meteorological Applications of Lightning Data, Am. Meteorol. Soc., Atlanta, GA, vol. 29 Jan-2 Feb 2006

Krehbiel, P.R., 2007. Thunderstorm electrification: an overview of recent observational results. 13th Intl. Conf. on Atmospheric Electricity, vol. 1. Beijing, China, pp. 190-193.
Lang, T.J., Rutledge, S.A., Dye, J.E., Venticinque, M., Laroche, P., Defer, E., 2000. Anomalously low negative cloud-to-ground lightning flash rates in intense convective storms observed during STERAO-A. Mon. Weather. Rev. 128, 160-173.

Lang, T.J., et al., 2004. The Severe Thunderstorm Electrification and Precipitation Study (STEPS). Bull. Am. Meteorol. Soc. 85, 1107-1125.

MacGorman, D.R., Burgess, D.W., Mazur, V., Rust, W.D., Taylor, W.L., Johnson, B.C., 1989. Lightning rates relative to tornadic storm evolution on 22 May 1981. J. Atmos. Sci. 46, 221-250.

MacGorman, D.R., Rust, W.D., Krehbiel, P.R., Bruning, E.C., Wiens, K.C., 2005. The electrical structure of two supercell storms during STEPS. Mon. Weather. Rev. 133, 2583-2607.

Mansell, E.R., MacGorman, D.R., Ziegler, C.L., Straka, J.M., 2005. Charge structure and lightning sensitivity in a simulated multicell thunderstorm. J. Geophys. Res. 110 (D12). doi:10.1029/2004JD005287.

Montanyà, J., Pineda, N., March, V., Illa, A., Romero, D., Solà, G., 2006a. Experimental evaluation of the Catalan Lightning Detection Network. 19th International Lightning Detection Conference, Tucson, US.

Montanyà, J., Pineda, N., Soula, S., March, V., 2006b. Total lightning activity and electrostatic field in a hail-bearing thunderstorm in Catalonia. 19th International Lightning Detection Conference, Tucson, US.

Montanyà, J., Soula, S., Pineda, N., 2007. A study of the total lightning activity in two hailstorms. J. Geophys. Res. 112, D13118. doi:10.1029/2006JD007203.

Murphy, M.J., Pifer, A., Cummins, K.L., Richard, P., Cramer, J., 2002. The 2002 upgrade of the U.S. NLDN. 17th International Lightning Detection Conference, Tucson, US.

Orville, R.E., 2008. Development of the National Lightning Detection Network. Bull. Amer. Meteor. Soc. 89 (2), 180-190.

Pérez Puebla, F., 2004. Cooperación entre las redes de rayos de España y Portugal. 28th Jornadas Científicas de la Asociación Meteorológica Española, Badajoz, Spain.

Pineda, N., Rigo, N.T., Bech, J., Soler, X., 2007. Lightning and precipitation relationship in summer thunderstorms: case studies in the North Western Mediterranean region. Atmos. Res. 85, 159-170.

Richard, P., Lojou, J.Y., 1996. Assessment of application of storm cell electrical activity monitoring to intense precipitation forecast. 10th International Conference on Atmospheric Electricity. Osaka, Japan, pp. 284-287.

Rivas Soriano, L., de Pablo, F., Tomas, C., 2005. Ten-year study of cloud-toground lightning activity in the Iberian Peninsula. J. Atmos. and Sol-Terr. Phys. 67 (16), 1632-1639.

Rust, W.D., MacGorman, D.R., 2002. Possibly inverted-polarity electrical structures in thunderstorms during STEPS. Geophys. Res. Lett. 29 (12), 1571. doi:10.1029/2001GL014303.

Rust, W.D., et al., 2005. Inverted-polarity electrical structures in thunderstorms in the Severe Thunderstorm Electrification and Precipitation Study (STEPS). Atmos. Res. 76 (1-4), 247-271.

Soula, S., Seity, Y., Feral, L., Sauvageot, H., 2004. Cloud-to-ground lightning activity in hail-bearing storms. J. Geophys. Res. 109 (D2). doi:10.1029/ 2003JD003669.

Tessendorf, S.A., Wiens, K.C., Rutledge, S.A., 2007. Radar and lightning observations of the 3 June 2000 electrically inverted storm from STEPS. Mon. Weather. Rev. 135, 3665-3681.

Wiens, K.C., Rutledge, S.A., Tessendorf, S.A., 2005. The 29 June 2000 supercell observed during STEPS. Part II: lightning and charge structure. J. Atmos. Sci. 62, 4151-4177.

Weiss, S.A., Rust, W.D., MacGorman, D.R., Bruning, E.C., Krehbiel, P.R., 2008. Evolving complex electrical structure of the STEPS 25 June 2000 multicell storm. Mon. Weather. Rev. 136, 741-756.

Williams, E.R., 2001. The electrification of severe storms. Meteorol. Monog. 28 (50), 527-561.

Williams, E., Boldi, B., Matlin, A., Weber, M., Hodanish, S., Sharp, D., Goodman, S., Raghavan, R., Buechler, D., 1999. The behavior of total lightning activity in severe Florida thunderstorms. Atmos. Res. 51, 245-265. 